\title{
THE COMBINED USE OF LONG-TERM MULTI-SENSOR INSAR ANALYSIS AND FINITE ELEMENT SIMULATION TO PREDICT LAND SUBSIDENCE
}

\author{
M. Gharehdaghi ${ }^{1, *}$, A. Fakher ${ }^{2}$, A. Cheshomi ${ }^{3}$ \\ ${ }^{1}$ MSc. Student, School of Civil Engineering, College of Engineering, University of Tehran, Tehran, Iran - \\ M.Gharedaghi@ut.ac.ir \\ ${ }^{2}$ Civil Engineering Department, University of Tehran, Tehran, Iran - Afakher@ut.ac.ir \\ ${ }^{3}$ Department of Engineering Geology, School of Geology, College of Science, University of Tehran, Tehran, Iran - \\ A.Cheshomi@ut.ac.ir
}

KEY WORDS: Land Subsidence, Ground water depletion, InSAR data, Numerical Simulation, Finite Element Method, Plaxis 2D, Tehran

\begin{abstract}
:
Land subsidence in Tehran Plain, Iran, for the period of 2003-2017 was measured using an InSAR time series investigation of surface displacements. In the presented study, land subsidence in the southwest of Tehran is characterized using InSAR data and numerical modelling, and the trend is predicted through future years. Over extraction of groundwater is the most common reason for the land subsidence which may cause devastating consequences for structures and infrastructures such as demolition of agricultural lands, damage from a differential settlement, flooding, or ground fractures. The environmental and economic impacts of land subsidence emphasize the importance of modelling and prediction of the trend of it in order to conduct crisis management plans to prevent its deleterious effects. In this study, land subsidence caused by the withdrawal of groundwater is modelled using finite element method software Plaxis 2D. Then, the model was verified using InSAR data. The results were in good agreement with the measurement results. The calibrated model was used to predict the land subsidence in future years. It could predict future subsidence for any assumed rate of water depletion.
\end{abstract}

\section{INTRODUCTION}

Land subsidence is defined as the differential displacement of the ground surface with respect to surrounding terrain or sea level. There are a number of natural causes such as tectonic motion and sea level rise introduced as a reason for land subsidence. Land subsidence may also happen as a result of human activities such as withdrawal of groundwater, oil and gas, the extraction of coal and ores and underground excavation for tunnel and cavern $\mathrm{Hu}$ et al.,2004). Although displacement occurred as a result of land subsidence is mainly downward, the horizontal component of deformation can lead to deteriorating effects. Withdrawal of groundwater due to its impact on the compaction of the susceptible aquifer system is a significant reason causing land subsidence. One of the other reasons for land subsidence is subsidence as a result of extraction of fluids such as water, crude oil and natural gas from subsurface formation. (Galloway and Burbey, 2011). Land subsidence occurs in plenty of cities around the world because of geologic settings and the reduction of groundwater levels as a result of an increase in the groundwater demand due to population growth and intensifying industry and agriculture. (Calderhead et al.,2011). Land subsidence has been reported in Vietnam (Thu et al,2000), Jakarta, Indonesia, West Bengal, India (Ganguli and Malay, 2011). Land subsidence in Iran has been reported in Mahyar, Nayshabour, and Kashmar (Lashkaripour et al., 2010, 2007,2006) and Mashhad (Motagh et al., 2007).

Land subsidence occurs in a valley where aquifer systems are partly made of fine-grained sediments, and groundwater level has decreased. The granular skeleton of the aquifer system as well as the fluid pressure of the groundwater that fills the intergranular pore space support the pore structure of a sedimentary aquifer system (Meinzer,1928). When pore-fluid pressure decreases as a consequence of withdrawal of groundwater and reduction of groundwater level, the skeleton should support most of the weight of overlying layers. Hence, the reduction in pore-fluid pressure increases the intergranular load, or effective stress, on the skeleton. The alteration in effective stress leads to the deformation of the skeleton- an increase in the effective stress results in skeletal compression, and a decline causes expansion. The vertical component of this deformation sometimes causes irreversible compaction of the aquifer system and land subsidence. An aquifer skeleton that contains fine-grained sediments, such as silt and clay, is considerably more compressible than the ones containing coarse-grained sediments, such as sand and gravel. In the cases that the stress imposed on the skeleton is smaller than the previous maximum effective stress, the deformation of the aquifer system is elastic (recoverable). The Maximum historical effective stress imposed on the aquifer system, sometimes the result of the lowest groundwater level, is called the "pre-consolidation stress". If stresses are greater than the pre-consolidation stress, rearrangement of the fine-grained sediments occurs in order to make a more stable structure at higher stresses. This rearrangement causes an irrecoverable reduction of pore volume and, hence, inelastic compaction of the aquifer system. (Riley,1998)

Predictive approaches for land subsidence are classified into five categories: (i) statistical methods; (ii) one-dimensional numerical method; (iii) quasi-3D seepage model; (iv) 3D seepage model; (v) fully coupled 3D model (Xu et al., 2008). Numerical models are beneficial in assessing of the evolution of land subsidence due to groundwater pumping, and are at present the most powerful predictive tool in evaluating potential future land subsidence

\footnotetext{
* Corresponding author
} 
developments. The paucity of data remains a major limitation to model applications and the reliability of their predictions. (Calderhead et al.,2011)

A number of tools are used to measure and monitor land subsidence due to extraction of groundwater including first order levelling (Bell 1981; Bell et al. 2002; Bell and Price 1991), borehole and tape extensometers (Carpenter 1993; Carruth et al. 2007; Pope and Burbey 2004; Riley 1969), and Global Positioning System (GPS) networks (Bell et al. 2002; Ikehara et al. 1998; Ikehara and Phillips 1994; Sneed and Galloway 2000). Recently, interferometric synthetic aperture radar (InSAR) has emerged as a powerful remote sensing tool to measure and monitor vertical surface displacements with time (Amelung et al. 1999; Bell et al. 2002; Galloway et al. 1999; Hoffmann et al. 2001; Massonnet and Feigl 1998; Rosen et al. 2004). The ability of InSAR for providing useful information to geomorphologists and hydrologists has been less recognized (Smith, 2002).

In the late 1950s, the idea of imaging the Earth first emerged, yet the scientific use began with the Seasat satellite in 1978. The early images of ground echoes were first considered to be undesirable noise. They became a useful signal to study large areas as radars were installed on airplanes and later satellites (Massonet et al., 1998).

InSAR data have been utilized in previous investigations of land subsidence caused by earthquakes (Massonet et al., 1993), volcanoes (Masson et al., 1995), and land subsidence (Massonet et al.,1997; Fielding et al., 1998; Galloway et al., 1998). Subsequent images from a side-looking radar mounted on a satellite is used by InSAR for estimation of vertical displacement of the ground surface associated with land subsidence. An antenna transmits a pulsed train of microwaves from a sidelooking satellite-borne radar. The waves are reflected by the earth, and the same antenna receive and record them as a continuous image along the track of the satellite. The same area of ground is re-imaged in each orbital repetition cycle of the satellite. Differentiating the phase differences between two radar images of a specific area leads to the creation of interferograms that are helpful for measurement of vertical displacement of the ground surface (Galloway and Hoffmann, 2007).

The vertical displacement estimated by InSAR is not an absolute value, but rather a relative value which depends on the orbital repetition cycle of the satellite. Various factors influence the accuracy of InSAR result. Therefore, corrections such as phase variations within a pixel, orbital trajectories, topography and atmospheric conditions should be applied in order to derive more precise results. (Massonnet and Feigl, 1998). InSAR can depict the centimetre-scale ground subsidence resulted by the exploitation of groundwater, petroleum, or coal. Interferometric observations of most researchers have been successfully validated with ground-based survey measurements (Smith, 2002).

Results from InSAR analysis can be used for calibration of numerical methods that simulate land subsidence caused by the exploitation of groundwater. InSAR data were used to calibrate numerical modelling by Herrera et al. (2009) and Tomas et al. (2010).

Overall, the presented paper is mainly aimed to use results from a long-term multi-sensor InSAR analysis and finite element simulation to predict land subsidence in Tehran.

\section{GEOLOGICAL AND HYDROLOGICAL INFORMATION}

Tehran Basin with the area of approximately $2250 \mathrm{~km}^{2}$ is located in Tehran province between the Alborz Mountains to the north and the Arad and Fashapouye Mountains to the south. It is a semiarid area and has relatively flat and gently sloping topography. Land subsidence occurred in the southwestern part of the basin due to the withdrawal of groundwater. A subsidence area of $415.64 \mathrm{~km}^{2}$ is located at $35^{\circ} 30^{\prime} \mathrm{N}$ to $35^{\circ} 42^{\prime} \mathrm{N}$ latitude and $50^{\circ}$ $55^{\prime} \mathrm{E}$ to $51^{\circ} 23^{\prime} \mathrm{E}$ longitude (GSI, 2005).

The hydrogeological units of the southwestern plain are divided into the aquifers and aquitards that constitute the region's aquifer system. The hydrogeological units consist of three aquifers and three aquitards:

- Aquifer 1 (shallow aquifer) extending down from $7 \mathrm{~m}$ to more than $30 \mathrm{~m}$.

- Aquifer 2 extending down from $35 \mathrm{~m}$ to more than $65 \mathrm{~m}$.

- Aquifer 3 (deep aquifer) extending downward from $70 \mathrm{~m}$.

Deep aquifer (3) is the major aquifer for groundwater extraction in the region. This aquifer is mainly composed of fine alluvial sand and silty sand with a thickness of 2 to $20 \mathrm{~m}$. The maximum depth of drilling in this area is $100 \mathrm{~m}$; thus, the lower boundary of the aquifer 3 is not precisely known. It appears that the thickness of this aquifer is greater than of the other two (GSI, 2005).

The groundwater level has been measured on a monthly basis since 1996 by Tehran's regional water authority in several wells located in different places across Tehran. Although the piezometric head of the wells are measured monthly, many intermittent gaps exist in the data record. Groundwater has its lowest levels in northeast part of the area, but it is higher in the southern and eastern part and reaches to the depth of $2 \mathrm{~m}$ in the southeast of the area. The groundwater flow direction is from the north to the south-southeast (GSI,2005). Considering the fact that land subsidence in Tehran is highly related to exploitation of groundwater, the data record of the piezometric head of wells are used in numerical simulation of land subsidence at points where surface displacements were reported by InSAR data.

Alluvial aquifers usually contain different proportions of gravel, sand, silt, and clay deposited as layers and lenses of varying thicknesses. Tehran alluvial deposits consist of four stratigraphic units A (Hezardarreh formation), B (Kahrizak formation, Qt1), C (Tehran alluvial formation, Qt2), and D (recent alluvium) (Rieben, 1955).

Geophysical investigations were carried out in the studied area in order to obtain more information about the geological and hydrological features. The map indicating changes in the thickness of alluvium were proposed by the interpretation of geophysical data in Figure 1 (GSI,2005). Thickness of the alluvium reaches more than $400 \mathrm{~m}$ in the northern part and about $300 \mathrm{~m}$ in the northwest of the area. In some points in north, east, southeast, and southwest of the area, the thickness of the alluvium is less than $25 \mathrm{~m}$ in accordance with arising in the level of bedrock. 


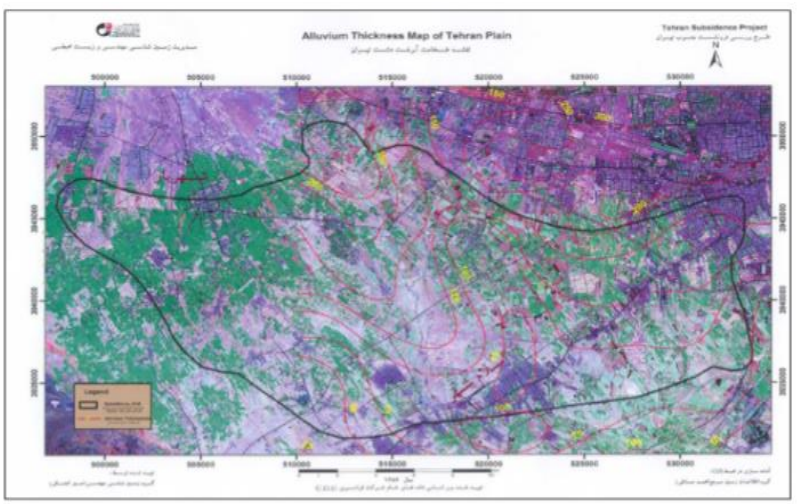

Figure 1. Alluvium thickness map of Tehran plain (GSI,2005)

\section{INSAR DATA}

There are a number of studies investigating the land subsidence in Tehran by using various methods. Although the conventional InSAR technique has high capabilities, it has some limitations with atmospheric disturbances and lack of image coherence (Foroughnia et al., 2019). Some investigations are carried out to improve the phase quality (Azadnezhad et al., 2019). Considering all the strong points and weaknesses, the data provided by Motagh et al. (2018) is used in the presented paper. Remote sensing radar interferometry measurements were carried out by Motagh et al. (2018). SAR images from the Envisat, ALOS, TerraSAR-X, and Sentinel-1 were used to investigate land subsidence in Tehran. In this study, the results of an Interferometric Synthetic Aperture Radar (InSAR) time series analysis of Tehran using different SAR data between 2003 and 2017 are presented. By constructing more than 400 interferograms derived from 39 Envisat ASAR (C-band), 10 ALOS PALSAR (L-band), 48 TerraSAR-X (X-band), and 64 Sentinel-1 (C-band) SAR datasets, displacement time series from interferometric observations using the Small Baseline (SB) technique are compiled. Datasets of different satellites have different time period coverage. Three Envisat datasets and one ALOS dataset span 2003 to 2010. The Envisat data were collected in both ascending and descending orbits, but the ALOS data were only collected in an ascending orbit. After a two-year gap, three ascending TerraSAR-X datasets cover the study area between 2012 and 2014. At last, Sentinel-1 data in both ascending and descending paths cover a two-year period between 2015 and 2017 (Matagh et al., 2018).

SAR datasets that were used in Motagh's study have different spatial coverage. Sentinel-1dataset covers all the agricultural areas in the Tehran plain. By contrast, the Envisat and ALOS datasets mostly cover the subsidence basin to the southwest of Tehran. A small area near Tehran is covered by TerraSAR-X datasets. Acquisitions of Sentinel-1 and TerraSAR-X are semiregular. While, the Envisat and ALOS datasets have regular temporal distributions, and there are many missing acquisitions (Motagh et al., 2018). SAR interferometry was conducted using Single Look Complex(SLC) images. The precise orbit data of satellite was used to re move the flat-earth phase. 3-arcsecond SRTM DEM were used to calculate and remove the topographic phase from the interferograms. Afterward, the remaining phase mainly contains the displacement, atmospheric artifact, and noise. The atmospheric artifact in InSAR consists of phase delays in the ionosphere and troposphere. In the study area, no clear evidence of ionospheric delays was shown in visual inspection of the interferograms even for L-band data except for some long- wavelength phase ramps across some of the interferograms, which might be caused by the ionospheric delay. These ramps are mixed with the previously mentioned orbital ramps and can be corrected by the trend removal. Tropospheric delays are generated by vertical variations, long-wavelength lateral variations, or short-wavelength turbulence in the atmosphere (Bekaert et al., 2015). The atmospheric delay resulted by vertical variations is highly correlated with the topography. Nonetheless, the topography in the study area is very smooth with a slight north-south slope; Thus, this effect is negligible. The other two sources of tropospheric artifacts can produce $\mathrm{cm}$-scale errors in the interferograms. The part which is not temporally correlated is estimated and removed during the time series analysis (Motagh et al.,2018).

All of the SLC SAR images are coregistered and resampled to a reference SAR frame in order to generate the stack of small Baseline interferograms for each dataset. Then, using the SAR images in a common geometry, subsidence interferograms are produced. The unwrapped interferograms of the subsidence network are inverted in a least-squares adjustment to recover the displacement time series and the average rate of displacement. Errors should be filtered as much as possible to attain a reliable estimation of displacement. The time span of each individual SAR dataset used in this study is restricted to a few years. Moreover, the period between 2003 and 2010 is only covered by haphazard data acquisitions of Envisat and ALOS. This impedes obtaining homogeneous and long-term information about the dynamics of land subsidence in the study area. (Motagh et al., 2018). Joining the InSAR time series derived from various datasets enables us to obtain a long time series with a higher temporal resolution (Castellazzi et al.,2017).

Motagh et al. (2018) compared the results derived from InSAR with levelling measurements and showed that they are generally in good agreement. The precision of the displacement rates is better than $0.5 \mathrm{~cm} / \mathrm{yr}$ (Motagh et al., 2018).

The interferogram proposed by Motagh et al. (2018) identifies three dominant subsidence features: (1) The southwest of Tehran, (2) Near IKA international airport, (3) Near Varamin (Motagh et al., 2018).

The largest deformation feature is reported in the area located in the southwest of Tehran, east of Malard and north of Eslamshahr. Envisat results report that the maximum rate of land subsidence in this area is more than $25 \mathrm{~cm} /$ year from 2003 to 2005 . Nevertheless, it decreased to approximately $20 \mathrm{~cm} /$ year based on Sentinel-1 results. Motagh et al. (2018) suggest that groundwater management and reduced rate of pumping accounts for the slightly lower rate of land subsidence in recent years. Few smaller subzones exist in the main subsidence bowl which are illustrated by dashed lines in Figure 2 .

Slight changes are seen in the subsidence pattern of sub-zone one and two over 15 years. In contrast, sub-zone three is considerably spreading eastward, which puts the urban area of Tehran under jeopardy of deteriorating effects of land subsidence. The principal reason justifying the eastward expansion of the subsidence area is the augment in demand for groundwater in the urban area. Land subsidence has affected many buildings in a large urban area of approximately $40 \mathrm{~km}^{2}$ north of the Azadegan Expressway. It has also damaged some infrastructure, including two railways (Tehran-Qom and Tehran-Tabriz), The Tehran Metro line 3 and several high ways (Motagh et al., 2018). 


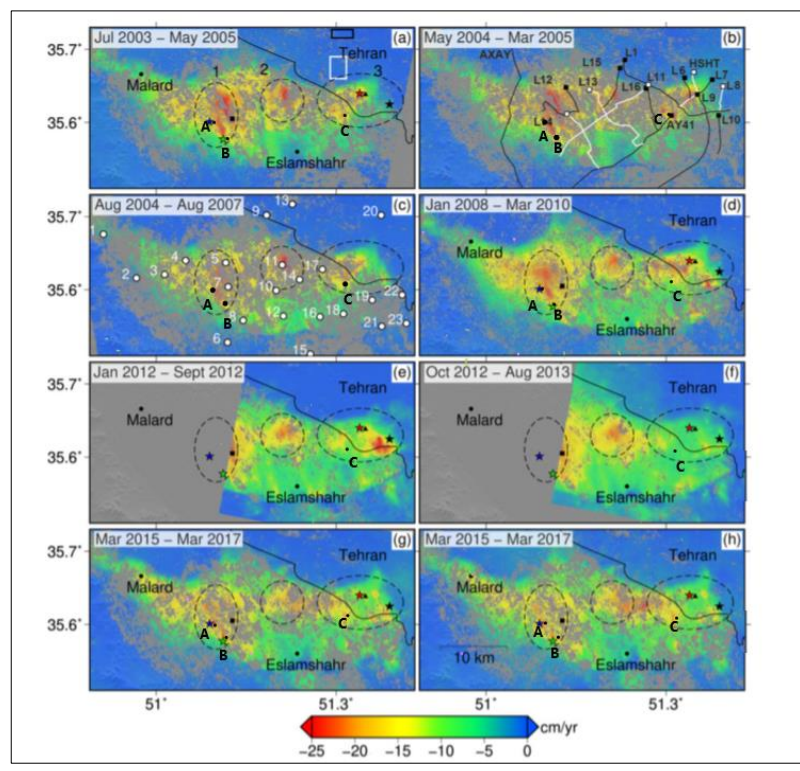

Figure 2. Average subsidence rates in the southwest of Tehran (Motagh et al., 2018)

\section{NUMERICAL MODELING}

\subsection{Model description}

Land subsidence in the presented study was simulated using finite element software, PLAXIS 2D. First, the geometry of the problem was modelled using a plane strain two-dimensional model. A relatively large working area of $200 \mathrm{~m}$ in the horizontal direction was used in order to minimize the boundary effects. The depth of the model was chosen based on the depth of bedrock at each point using Figure 1. The geometry contains a horizontal soil surface. Fixed boundary condition was set at the bottom of the model, and vertical sides of the model were only fixed horizontally and free in the vertical direction. The finite element mesh is based on 15-node elements. The 15-noded triangle element provides a fourth order interpolation for displacements. Soil layers were defined according to the soil profiles. Then, proper geotechnical parameters were assigned to the model. The initial level of groundwater was applied to the model. Based on the phreatic level, which is given as input data, pore pressures and external water pressures can be generated. A phreatic level is the indicator of a series of points where the water pressure is zero, and the hydrostatic water pressure will increase linearly with depth according to the specified water weight. After the input of phreatic levels, the water pressures can be produced. Groundwater pressure is used as input data for deformation analysis. The water pressures should be activated in a calculation by the activation of the soil weight using the SMweight Parameter, which represents the proportion of gravity that is applied. The value of 1 can be accepted, which implies that the full soil weight is activated. In fact, stress points in elements with a zero steady pore pressure are considered to be unsaturated, whereas stress points that have a non-zero steady pore pressure are considered to be saturated. Thus, the value of the pore pressure determines whether the saturated soil weight ( $\gamma$ sat) or the unsaturated soil weight ( $\gamma$ unsat) is applied in a deformation analysis.

Consolidation boundaries should be appropriately considered for consolidation analysis, and in this model, vertical boundaries were closed. Mohr-Coulomb model was selected as the constitutive model for the soil. Mohr-Coulomb model is widely used in modelling geotechnical problems, and according to its simplicity was chosen in the presented study. The other main advantage of Mohr-Coulomb in comparison to other constitutive models is that it needs fewer input variables which is important regarding lack of geotechnical information in the studied area. The drained and undrained behaviour of soil was considered for granular and fine-grained soils, respectively.

Stage construction was utilized for the analysis. In the first stage, initial stresses were generated. In general, the initial stresses at a stress point are as a result of the weight of the material above this point and the value of SMweight. The value of initial stress at each point is calculated using Equation 1.

$$
\sigma_{v .0}^{\prime}=\sum \operatorname{Mweight}\left(\sum_{i} \gamma_{i} \cdot h_{i}-p_{w}\right) \cdot \sigma_{h .0}^{\prime}=K_{0} \cdot \sigma_{v .0}^{\prime}
$$

Where $\gamma_{i}=$ the unit weight of individual layers

$h_{i}=$ the layer depth

$\mathrm{p}_{\mathrm{w}}=$ the initial pore pressure in the stress point.

After the generation of the initial stresses, the initial situation of the finite element method is complete. Hence, the finite element calculation can be executed. Therefore, determining the types of calculation to be performed and types of loading or construction stages to be activated in the calculations is the next necessary step.

In our finite element model for land subsidence, the groundwater level is decreased in the second stage, and deformation is calculated using plastic calculation. A Plastic calculation is used in the cases where the deformation should be calculated without taking the decay of excess pore pressures with time into account. The stiffness matrix in a normal elastic calculation is based on the original undeformed geometry. This type of calculations is proper in most practical geotechnical applications.

After the second phase of the construction, a consolidation phase is introduced to allow the excess pore pressure dissipate entirely. In this phase, the irrecoverable deformation of the soil will be calculated. A consolidation analysis examines the development or dissipation of excess pore pressures in water-saturated claytype soils as a function of time. Plaxis gives us the opportunity to perform accurate elastic-plastic consolidation analyses. The regulating equations of consolidation as used in Plaxis follow Biot's theory (Biot,1941). Darcy's law for fluid flow and elastic behavior of the soil skeleton are also assumed. The formulation is based on the small strain theory. According to Terzaghi's principle, stresses are divided into effective stresses and pore pressures:

$\sigma=\sigma^{\prime}+m\left(P_{\text {steady }}+P_{\text {excess }}\right)$

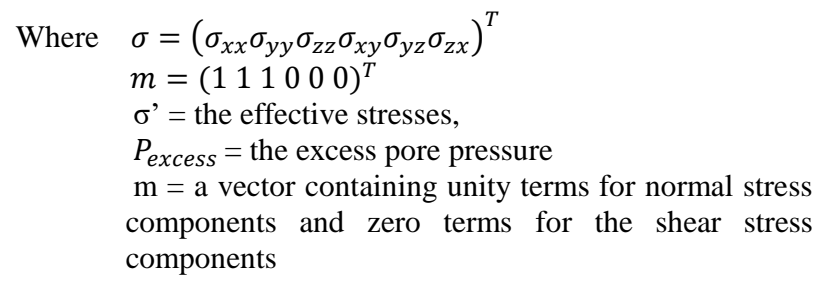

Within Plaxis $P_{\text {steady }}$ is defined as:

$P_{\text {steady }}=\sum$ Mweight $\cdot P_{\text {input }}$ 
Where $P_{\text {input }}$ is the pore pressure generated in the input program based on phreatic lines.

The constitutive equation is written in incremental form. Denoting an effective stress increment as $\dot{\sigma}^{\prime}$ and a strain increment as $\dot{\varepsilon}$, the constitutive equation is:

$\dot{\sigma}^{\prime}=M \cdot \dot{\varepsilon}$

Where $\varepsilon=\left(\varepsilon_{x x} \varepsilon_{y y} \varepsilon_{z z} \gamma_{x y} \gamma_{y z} \gamma_{z x}\right)^{T}$

And $\mathrm{M}$ represents the material stiffness matrix.

Material properties used in this study are obtained from borehole logs presented by site investigation and laboratory tests. Additionally, some modifications were carried out on the soil parameters from an engineering judgment perspective. Input variables for the Mohr-Coulomb model are young's module (E) as the basic stiffness modulus, Poisson's ratio (u), Cohesion (C), Friction angle $(\mathrm{F})$.

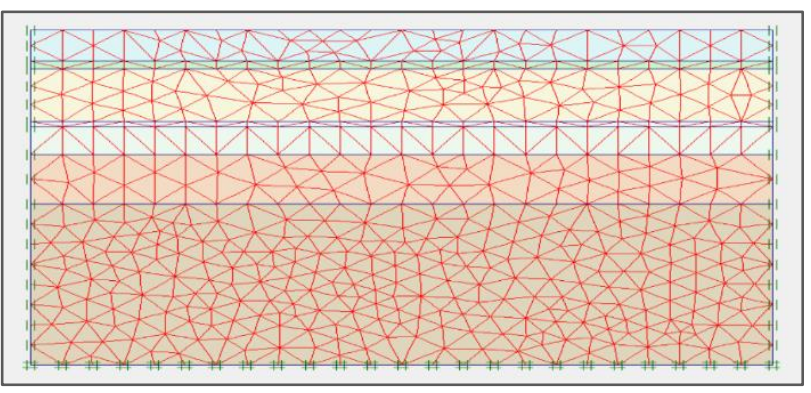

Figure 3. Numerical modelling

\subsection{Verification}

The model previously defined has been used to simulate land subsidence in 3 points (A, B, C) shown in Figure 2. These points were chosen to verify the calculation of land subsidence by the finite element model, since they are the representatives of various rates of land subsidence in the area. The geotechnical information of each point was obtained from borehole logs presented in the geotechnical dataset of Iran. Some modifications on soil parameters were carried out using geotechnical tables suggesting characteristic of different types of soils by Burt Look. Geotechnical information of boreholes is presented in Table 1 .

\begin{tabular}{|c|c|c|c|c|c|c|}
\hline \multicolumn{7}{|c|}{ Borehole A } \\
\hline Layer & Depth (m) & $\begin{array}{c}\text { Cohesion } \\
(\mathrm{kPa})\end{array}$ & $\begin{array}{c}\begin{array}{c}\text { Friction } \\
\text { angle } \\
\left({ }^{\circ}\right)\end{array} \\
\end{array}$ & $\begin{array}{c}\text { Elasticity } \\
\text { modulus } \\
\text { (Mpa) }\end{array}$ & $\begin{array}{c}\text { Poisson } \\
\text { ratio }\end{array}$ & $\begin{array}{c}\text { Permeability } \\
\text { (m/day) }\end{array}$ \\
\hline 1 & $0-12.5$ & 110 & \begin{tabular}{|l|}
14.3 \\
\end{tabular} & \begin{tabular}{|l|}
25 \\
\end{tabular} & 0.3 & $8.64 \mathrm{E}-07$ \\
\hline 2 & $12.5-15.5$ & 22 & 40 & 30 & 0.3 & $8.64 \mathrm{E}-03$ \\
\hline 3 & $15.5-37$ & 150 & 25 & 45 & 0.3 & $8.64 \mathrm{E}-07$ \\
\hline 4 & $37-38$ & 52 & 45 & 150 & 0.3 & 8.64 \\
\hline 5 & $38-50$ & 50 & 25 & 45 & 0.3 & $8.64 \mathrm{E}-07$ \\
\hline 6 & $50-70$ & 24 & 45 & 70 & 0.3 & 8.64 \\
\hline 7 & $70-100$ & 24 & 45 & 70 & 0.3 & 8.64 \\
\hline \multicolumn{7}{|c|}{ Borehole B } \\
\hline Layer & Depth (m) & $\begin{array}{c}\text { Cohesion } \\
(\mathrm{kPa})\end{array}$ & $\begin{array}{c}\begin{array}{c}\text { Friction } \\
\text { angle } \\
\left({ }^{\circ}\right)\end{array} \\
\end{array}$ & \begin{tabular}{|c}
$\begin{array}{c}\text { Elasticity } \\
\text { modulus } \\
\text { (Mpa) }\end{array}$ \\
\end{tabular} & oisson rat & $\begin{array}{c}\text { Permeability } \\
\text { (m/day) }\end{array}$ \\
\hline 1 & $0-10$ & 100 & 18 & 30 & 0.3 & $8.64 \mathrm{E}-07$ \\
\hline 2 & $10-14.5$ & 25 & 45 & 35 & 0.3 & $8.64 \mathrm{E}-03$ \\
\hline 3 & $14.5-35$ & 160 & 27 & 45 & 0.3 & $8.64 \mathrm{E}-07$ \\
\hline 4 & $35-38$ & 54 & 45 & 160 & 0.3 & 8.64 \\
\hline 5 & $38-53$ & 55 & 25 & 45 & 0.3 & $8.64 \mathrm{E}-07$ \\
\hline 6 & $53-72$ & 20 & 45 & 70 & 0.3 & 0.864 \\
\hline 7 & $72-100$ & 20 & 45 & 70 & 0.3 & 0.864 \\
\hline \multicolumn{7}{|c|}{ Borehole C } \\
\hline Layer & Depth (m) & phesion (kP & $\begin{array}{c}\text { Friction } \\
\text { angle } \\
\left({ }^{\circ}\right)\end{array}$ & \begin{tabular}{|c} 
Elasticity \\
modulus \\
(Mpa)
\end{tabular} & $\begin{array}{c}\text { Poisson } \\
\text { ratio }\end{array}$ & $\begin{array}{c}\text { Permeability } \\
\text { (m/day) }\end{array}$ \\
\hline 1 & $0-10$ & 110 & 14.3 & \begin{tabular}{|l|}
25 \\
\end{tabular} & 0.3 & $8.64 \mathrm{E}-07$ \\
\hline 2 & $10-30$ & 22 & 40 & 30 & 0.3 & $8.64 \mathrm{E}-03$ \\
\hline 3 & $30-50$ & 150 & 25 & 45 & 0.3 & $8.64 \mathrm{E}-07$ \\
\hline 4 & $50-100$ & 52 & 45 & 150 & 0.3 & 8.64 \\
\hline
\end{tabular}

Table 1. Geotechnical information at selected points (A, B, C)
Rate of land subsidence based on InSAR data at each point during 2015-2017 is presented in Table 2. Results from numerical modelling are in good agreement with the InSAR data available.

\begin{tabular}{|c|c|c|c|}
\cline { 2 - 4 } \multicolumn{1}{c|}{} & Point A & Point B & Point C \\
\hline years of & $\begin{array}{c}\text { Rate of land } \\
\text { subsidence } \\
(\mathrm{cm} / \text { year })\end{array}$ & $\begin{array}{c}\text { Rate of land } \\
\text { subsidence } \\
(\mathrm{cm} / \text { year })\end{array}$ & $\begin{array}{c}\text { Rate of land } \\
\text { subsidence } \\
(\mathrm{cm} / \text { year })\end{array}$ \\
\hline $2015-2017$ & $20-25$ & $20-25$ & $15-20$ \\
\hline
\end{tabular}

Table 2. Rate of land subsidence based on InSAR data at selected points (A, B, C)

\subsection{Calibration}

InSAR data available in the study area were used to calibrate the numerical model in order to obtain the ability to predict the rate of land subsidence in critical points. Sensitivity analysis was conducted to identify the most influential input parameters in the problem. According to the results of sensitivity analysis, the initial level of groundwater, decrease in groundwater level, Young's module of the thickest layer and depth of bedrock were the most important parameters.

\section{RESULTS}

A numerical and calibrated model can be used to predict rate of land subsidence in future years assuming any reasonable rate of water extraction. Based on the calculated results, the predicted rate of land subsidence in the selected points (points A, B, C) during 2015-2020 assuming the constant rate of groundwater pumping similar to $2015-2017$ is presented in Table3. The rate of land subsidence assuming doubled rate of water extraction in the selected points is presented in Table 4. The rate of land subsidence assuming half rate of water extraction in the selected points is presented in Table 5 .

\begin{tabular}{|c|c|c|c|}
\cline { 2 - 4 } \multicolumn{1}{c|}{} & Point A & Point B & Point C \\
\hline $\begin{array}{c}\text { Period } \\
\text { of years }\end{array}$ & $\begin{array}{c}\text { Annual rate of } \\
\text { land } \\
\text { subsidence } \\
\text { (cm/year) }\end{array}$ & $\begin{array}{c}\text { Annual rate of } \\
\text { land } \\
\text { subsidence } \\
\text { (cm/year) }\end{array}$ & $\begin{array}{c}\text { Annual rate of } \\
\text { land } \\
\text { subsidence } \\
\text { (cm/year) }\end{array}$ \\
\hline $2017-2019$ & 17.2 & 15.32 & 12.6 \\
\hline $2017-2020$ & 16.24 & 14.42 & 12.39 \\
\hline $2017-2021$ & 15.38 & 13.585 & 12.17 \\
\hline $2017-2022$ & 14.60 & 12.75 & 11.90 \\
\hline
\end{tabular}

Table 3. Predicted rate of land subsidence at selected points A,

$\mathrm{B}, \mathrm{C}$ assuming a constant rate of groundwater extraction

\begin{tabular}{|c|c|c|c|}
\cline { 2 - 4 } \multicolumn{1}{c|}{} & Point A & Point B & Point C \\
\hline $\begin{array}{c}\text { Period of } \\
\text { years }\end{array}$ & $\begin{array}{c}\text { Annual rate of } \\
\text { land } \\
\text { subsidence } \\
\text { (cm/year) }\end{array}$ & $\begin{array}{c}\text { Annual rate of } \\
\text { land } \\
\text { subsidence } \\
\text { (cm/year) }\end{array}$ & $\begin{array}{c}\text { Annual rate of } \\
\text { land } \\
\text { subsidence } \\
\text { (cm/year) }\end{array}$ \\
\hline $2017-2019$ & 30.77 & 27.17 & 24.33 \\
\hline $2017-2020$ & 27.48 & 23.87 & 23.25 \\
\hline $2017-2021$ & 24.2 & 20.57 & 22.09 \\
\hline $2017-2022$ & 21.00 & 17.27 & 20.80 \\
\hline
\end{tabular}

Table 4. Predicted rate of land subsidence at selected points A,

$\mathrm{B}, \mathrm{C}$ assuming doubled rate of groundwater extraction 


\begin{tabular}{|c|c|c|c|}
\cline { 2 - 4 } \multicolumn{1}{c|}{} & Point A & Point B & Point C \\
\hline $\begin{array}{c}\text { Period of } \\
\text { years }\end{array}$ & $\begin{array}{c}\text { Annual rate of } \\
\text { land } \\
\text { subsidence } \\
\text { (cm/year) }\end{array}$ & $\begin{array}{c}\text { Annual rate of } \\
\text { land } \\
\text { subsidence } \\
\text { (cm/year) }\end{array}$ & $\begin{array}{c}\text { Annual rate of } \\
\text { land } \\
\text { subsidence } \\
\text { (cm/year) }\end{array}$ \\
\hline $2017-2019$ & 9.35 & 8.11 & 6.43 \\
\hline $2017-2020$ & 8.73 & 7.97 & 6.35 \\
\hline $2017-2021$ & 8.6 & 7.66 & 6.30 \\
\hline $2017-2022$ & 8.33 & 7.40 & 6.27 \\
\hline
\end{tabular}

Table 5. Predicted rate of land subsidence at selected points A, $\mathrm{B}, \mathrm{C}$ assuming a half rate of groundwater extraction

\section{CONCLUSION}

1. In the presented study, InSAR time series investigation of land subsidence for the period of 2003-2017 and finite element modelling are successfully used to predict the rate of land subsidence in the south-western area of Tehran plain, Iran in future years.

2. The InSAR data indicate that the maximum rate of land subsidence in Tehran during the period of 2015-2017 is about 25 $\mathrm{cm} /$ year.

3. According to the calibrated model, if the rate of groundwater extraction in future years be as same as pumping rate during 2015-2017, the rate of land subsidence will decrease. If the rate of pumping groundwater increase in future years, the rate of land subsidence will grow to larger amounts.

4. Results from the finite element model indicate that the rate of land subsidence at each point decreases gradually overtime for any assumed rate of water extraction. The results are in good agreement with results derived by Motagh et al. (2018).

\section{REFERENCE}

Amelung, F., Galloway, D. L., Bell, J. W., Zebker, H. A., and Laczniak, R. J., 1999. "Sensing the ups and downs of Las Vegas: InSAR reveals structural control of land subsidence and aquifersystem deformation." Geology, 27(6), 483-486.

Bekaert, D., Walters, R., Wright, T., Hooper, A., Parker, D., 2015. Statistical comparison of InSAR tropospheric correction techniques. Remote Sens. Environ. 170, 40-47.

Bell, J. W., 1981. "Subsidence in Las Vegas Valley." Nevada Bureau of Mines and Geology Bulletin, 83.

Bell, J. W., Amelung, F., Ramelli, A. R., and Blewitt, G., 2002. "Land subsidence in Las Vegas, Nevada, 1935-2000: New geodetic data show evolution, revised spatial patterns, and reduced rates." Environmental \& Engineering Geoscience, 8(3), $155-174$.

Bell, J. W., and Price, J. G., 1991. "Subsidence in Las Vegas Valley, 1980-91-Final project report." Nevada Bureau of Mines and Geology, Open-File Report 93-4, 10 sect., 19 plates.

Biot, Maurice A. "General theory of three-dimensional consolidation." Journal of applied physics 12.2, 1941: 155-164.

Calderhead AI, Therrien R, Rivera A, Martel R, Garfias J, 2011. Simulating pumping-induced regional land subsidence with the use of InSAR and field data in the Toluca Valley, Mexico. Adv Water Resour34: 83-89. Thu et.al,2000
Carpenter, M. C., 1993. "Earth-fissure movements associated with fluctuations in ground-water levels near the Picacho Mountains, south-central Arizona, 198084." U.S. Geological Survey Professional Paper 497-H, 49.;

Carruth, R. L., Pool, D. R., and Anderson, C. E., 2007. "Land subsidence and aquifersystem compaction in the Tucson Active Management Area, south-central Arizona, 1987-2005." U.S. Geological Survey, Reston, Va., 27.

Castellazzi, P., Garfias, J., Martel, R., Brouard, C., Rivera, A., 2017. InSAR to support sustainable urbanization over compacting aquifers: The case of Toluca Valley, Mexico. Int. J. Appl. Earth Obs. Geoinf. 63, 33-44. doi: 10.1016/j.enggeo.2009.11.004.

Fielding, E.J., Blom, R.G., and Goldstein, R.M., 1998, Rapid subsidence over oil fields measured by SAR interferometry: Geophysical Research Letters, v. 27, p. 3,215-3,218.

Foroughnia, F., S. Nemati, Y. Maghsoudi, and D. Perissin. 2019. "An Iterative Psinsar Method for The Analysis of Large Spatiotemporal Baseline Data Stacks for Land Subsidence Estimation." International Journal of Applied Earth Observation and Geoinformation 74: 248-258. doi: 10.1016/j.jag.2018.09.018.

Galloway, D. L., Ingebritsen, S. E., Riley, F. S., Ikehara, M. I., and Carpenter, M. C., 1999. "The role of science." Land Subsidence in the United States, D. Galloway, D. Jones, and S. Ingebritsen, eds., U.S. Geological Survey Circular 1182, 141158.

Galloway, D.L, Hoffmann, J., 2007. The application of satellite differential SAR interferometry-derived ground displacements in hydrology. Hydrogeol. J. 15, 133- 154

Galloway, D.L., Burbey, T.J., 2011. Review: regional land subsidence accompanying groundwater extraction. Hydrogeol. J. 19, 1459-1486. http://dx.doi.org/10.1007/ s10040-011-0775-5.

Galloway, D.L., Hudnut, K.W., Ingebritsen, S.E., Philips, S.P., Peltzer, G., Rogez, F., Rosen, P.A., 1998. Detection of aquifer system compaction and land subsidence using interferometric synthetic aperture radar, Antelope Valley, Mojave Desert, California. Water Resour. Res. 34, 2573-2585.

Ganguli, Malay. "Groundwater withdrawal and land subsidence: A study of Singur Block, West Bengal, India." International Journal of Geomatics and Geosciences 2.2 (2011): 465.

ground subsidence study based on DInSAR data: Calibration of soil parameters and subsidence prediction in Murcia City (Spain), Engineering Geology 111, 19-30.

GSI, Geological Survey of Iran, 2005. Ground Subsidence Review at Tehran Plain-Shahryar (First Report) (84 pp., (in Persian))

Handbook of geotechnical investigation and design tables / Burt G. Look.

Herrera, G., Fernandez-Merodo, J., Tomas, R., Cooksley, G., Mulas, J., 2009. Advanced interpretation of subsidence in Murica (SE Spain) using A-DInSAR data-modeling and validation. Nat. Hazard Earth Syst. Sci. 9, 647-661. 
Hoffmann, J., Zebker, H. A., Galloway, D. L., and Amelung, F. (2001). "Seasonal subsidence and rebound in Las Vegas Valley, Nevada, observed by synthetic aperture radar interferometry." Water Rosources Research, 37(6), 1551-1566.

Hu, R.L., Yue, Z. Q., Wang, L.C., Wang, S.J., 2004. Review on current status and challenging issues of land subsidence in China, Journal of Engineering Geology 76 (2004) 65-77

Ikehara ME, Galloway DL, Fielding E, Bürgmann R, Lewis AS, Ahmadi B, 1998. InSAR imagery reveals seasonal and longerterm land-surface elevations changes influenced by groundwater levels and fault alignment in Santa Clara Valley, California. EOS Trans AGU Fall Meet Suppl 79(45), abstract U21A-15

Ikehara ME, Phillips SP, 1994. Determination of land subsidence related to ground-water level declines using global positioning system and leveling surveys in Antelope Valley, Los Angeles and Kern Counties, California, 1992. USGS Water Resour Invest Rep 94-4184. http://pubs.er.usgs.gov/usgspubs/wri/ wri944184. Cited 29 Sept 2006

Lashkaripour, G., Ghafouri, M., Kazemi, R., Damshenas, M., 2007. Land subsidence due to groundwater decline in Neyshabur plain. Fifth Conference of Engineering Geology and the Environment, Natural Disaster Research Institute, Tehran, Iran, pp. 1082-1091 (in Persian).

Lashkaripour, G., Ghafouri, M., Salehi, R., 2010. Land subsidence of southern Mahyar plain and effects of induced fissures on residential, industrial and agricultural. Fifth National Conference of Geology and the Environment, Islamic Azad University of Eslamshahr, Iran (6 pp., (in Persian)).

Lashkaripour, G., Rostami Barani, H., Kohandel, A., Torshizi, H., 2006. Decline in groundwater levels and land subsidence in the Kashmar plain. Proceeding of the International Conference on Earth Sciences, Tehran, Iran, pp. 2428-2438 (in Persian).

Massonnet, D., and Feigl, K. L., 1998. "Radar interferometry and its application to changes in the earth's surface." Reviews of Geophysics, 36, 441-500.

Massonnet, D., Holzer, T., and Vadon, H., 1997, Land subsidence caused by the East Mesa geothermal field, California, observed using SAR interferometry: Geophysical Research Letters, v. 24, p. 901-904.

Massonnet, D., Rossi, M., Carmona, C., Adragna, F., Peltzer, G., Feigl, K., and Rabaute, T., 1993, The displacement field of the Landers earthquake mapped by radar interferometry: Nature, $\mathrm{v}$. 364, p. 138-142.

Massonnet, D., Briole, P., and Arnaud, A., 1995, Deflation of Mount Etna monitored by spaceborne radar interferometry: Nature, v. 375, p. 567-570.

Meinzer OE, 1928. Compressibility and elasticity of artesian aquifers. J Geol 23(3):263-291 Riley,1998

Motagh, M., Djamour, Y., Walter, T.R., Wetzel, H.U., Zschau, J., Arabi, S., 2007. Land subsidence in Mashhad Valley, Northeast of Iran, results from InSAR leveling and GPS. J. Geophys. 168 (2), 518-526. http://dx.doi.org/10.1111/j.1365246x.2006.03246.x.
Pope, J. P., and Burbey, T. J., 2004. "Multiple-aquifer characterization from single borehole extensometer records." Ground Water, 42(1), 45-58.

Rieben, E.H., 1955. The geology of the Tehran plain, American Journal of Science, vol.253, 617-639. doi:10.2475/ajs.253.11.617.

Riley, F.S., 1969. Analysis of borehole extensometer data from central California. In: Tison, L.J. (Ed.), Land subsidence, vol.2, pp. $423-431$

Rosen, P. A., Henley, S., Peltzer, G., and Simons, M., 2004. "Updated repeat orbit interferometry package released." EOS, Transactions American Geophysical union, 85(5), 47.

S. Azadnejad, Y. Maghsoudi \& D. Perissin, 2019. Investigating the effect of the physical scattering mechanism of the dualpolarization sentinel-1 data on the temporal coherence optimization results, International Journal of Remote Sensing, 40:18, 7033-7047, DOI: 10.1080/01431161.2019.1597309

Smith LC, 2002. Emerging applications of interferometric synthetic aperture radar (InSAR) in geomorphology and hydrology. Ann Am Geogr 92(3):385-398

Sneed M, Galloway DL, 2000. Aquifer-system compaction and land subsidence: measurements, analyses, and simulations: The Holly site, Edwards Air Force Base, Antelope Valley, California. USGS Water Resour Invest Rep 00-4015. http://ca.water. usgs.gov/archive/reports/wrir004015/. Cited 29 Sept 2006

Tomás, R., Herrera, G., Delgado, J., Lopez-Sanchez, J.M., Mallorquí, J.J., Mulas, J., 2010. A

Xu, Y., Shen, S., Cai, Z., Zhou, G., 2008. The state of land subsidence and prediction approaches due to ground water withdrawal in China. Nat. Hazards 45, 123-135. 